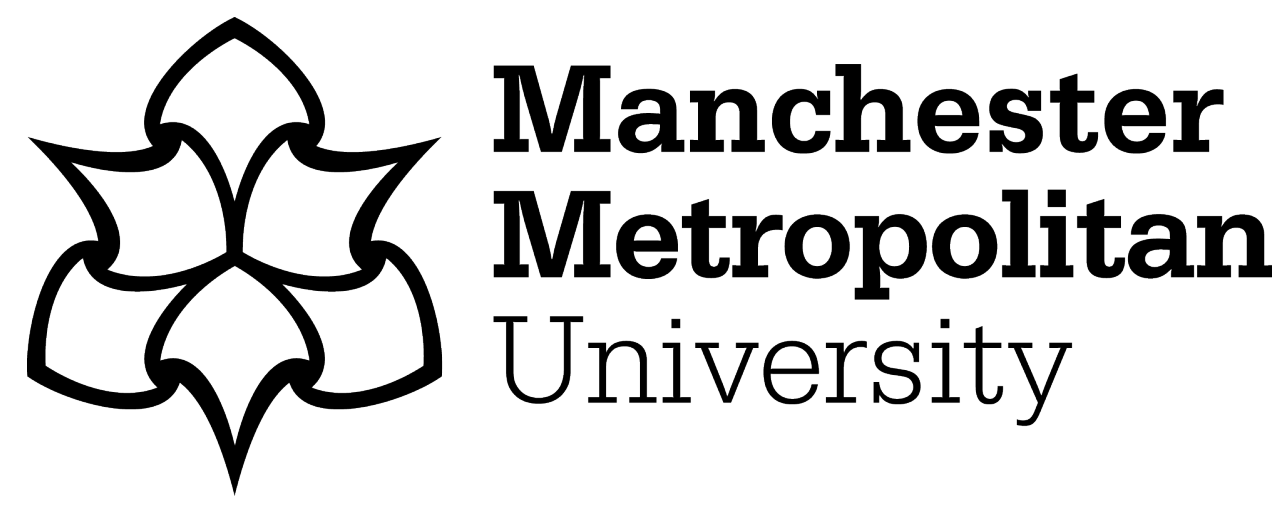

Sykas, Philip A. (2009) Fustians in Englishmen's dress: from cloth to emblem. Costume, 43 (1). pp. 1-18. ISSN 0590-8876

Downloaded from: https: //e-space.mmu.ac.uk/74454/

Version: Accepted Version

Publisher: Maney Publishing

DOI: https://doi.org/10.1179/174963009x419692

Please cite the published version 
DRESS

\title{
Fustians in Englishmen's Dress: from Cloth to Emblem
}

\author{
By PHILIPA. SYKAS
}

This paper examines the naure of the textiles known as fustians, originally imported but later manufactured in England. The focus is on eighteenth-century England when fustians underwent further development into modern cloth types. Evidence of the use of fustians for men's dress, and the status of those who wore them, is explored to shed further light on the developments leading up to the association of fustian with workingclass men. The paper is based on a presentation delivered at the Costume Society Symposium: Town and Country Style in 2007.

The association of fustians with rural men was familiar enough in the mid-nineteenth century to feature in a village festival sketched in the children's classic, Tom Brown's Schooldays. From the churchyard, the field is seen 'thronged with country folk; the men in clean, white smocks or velveteen orfustian coats'. ${ }^{1}$ The book was based on the author's own experiences at Rugby school from 1834 to 1842, and makes use of clothing to mark class difference and social status in the countryside. During the same years, the labouring men of England's towns also claimed fustians as their own. So much so, that the Chartist leaderFeargus O’Connor (1796?-1855) proclaimed'fustian jackets, blistered hands, and unshorn chins' as the proud emblems of the urban working man. ${ }^{2}$ When did fustian become such a part of the labouring scene across both urban and rural settings? This paper examines the use of fustians in the previous century to shed light on the evolution of associations between fustian and men's dress.

Most fabric names have fluctuating and variable meanings, but the term fustian is even more confusing than usual. This is not only because fustians are a broad class of textiles encompassing a range of weave structures, but because they changed over time by the 
DRESS

use of different fibres and finishes. To add to the difficulties, historians have used the term in a loose way, and also as a translation of foreign terms coming from widely varying contexts.

The manufacture of fustians in Europe probably arose from Islamic precedents, and is thought to have begun with the rise of the cotton trade in twelfth-century Genoa and Venice. This cotton was distributed to the textile industries of Lombardy where it was woven into all-cotton and cotton mixture cloths (with linen, hemp and wool) known collectively as fustagni. ${ }^{3}$ By the end of the century, such cotton-based cloths were exported widely from North Italy; Maureen Mazzaoui was able to trace one medieval document referring to the sale of 'fustians', thought to be of Italian make, in London. ${ }^{4}$ Mazzaoui tracked the rise of the production of cotton-based cloth, centred in Milan and Cremona and its gradual decline from the end of the fourteenth century at which time the Swabian towns of Ulm and Augsburg across the Alps began to produce similar fabrics. There, such cloths were made of locally-sourced linen warps mixed with highquality imported cotton wefts, and were known as barchent. Hermann Kellenbenz described the industry in the Ulm region in the fifteenth and sixteenth centuries, and its penetration into European markets. ${ }^{5}$ He cites an important contract of 1546, between an agent dealing in Ulm fustians and the court of Westminster, for a loan of $£ 40,000$ to be taken one-quarter in fustian cloth. ${ }^{6}$ The English documentation for this agreement refers to the cloth as fustian rather than barchent, thus indicating that the meaning of the English word was set prior to the experience of the Ulm cloths. ${ }^{7}$

In the reign of Henry VII, law reports for 1495 described measuresbrought in to prevent deceitful finishing of fustyans imported from unspecified 'parts beyond' 8 These cloths were to be correctly raised and then shorn to a smooth surface with the 
broadshears, but the malpractice involved singeing the nap with lit candles. Given the flammability of cotton fibre, it is difficult to imagine that these fustians were the linenand-cotton mixture fabrics of Swabia, especially as the process was said to be carried out in the attics of houses. It thus appears that a foreign cloth with a woollen nap, also known as fustian, had entered the English market by the fifteenth century. This production might have begun in imitation of the linen-and-cotton mixture cloth; nevertheless we can see that, in late-fifteenth century England, fustian was accepted as a generic descriptor of a recognisable cloth type, rather than indicating a specific fibre composition. $^{9}$

Home production of fustians in England probably began with wool or wool-mixture cloths. A statute of 1554 allowed Norwich weavers to call their napped materials of cotton or flax mixed with wool, 'fustian of Norwich. ${ }^{, 10}$ And as late as 1710 , fustian was used to refer to wools; for example, the Index to the Journals of the House of Commons then cross-referenced fustian manufacturesto woollen manufactures. ${ }^{11}$ Writing in the same year, Sansom implies a continuing need to clarify the type of fustian when he writes, ' 17 Yards and $1 / 4$ of Cotton-Fustian worth $17 \mathrm{~s} .3 \mathrm{~d}$ '. ${ }^{12}$ The lack of clarity about the cloth was probably due to the eventual surpassing of Norwich production by the Lancashire fustian industry that began around 1600 using linen warps and cotton wefts. This starting date is confirmedby a petition to parliament dated to 1621 in which the fibre content of the fustian is clearly indicated..$^{13}$ Thus, seventeenth century English references to fustian might apply to either wool-based cloth or the linen-and-cotton mixtures. However, sometime in the first quarter of the $1700 \mathrm{~s}$, the term seems to be more securely understood to indicate mixture cloths having a linen warp and cotton weft. ${ }^{14}$ For example, Ward's Modern World Disrob'd, published in 1708, speaks of the 'Linnen-Draper' measuring his Fustian without the need for any qualifier. ${ }^{15}$ 
The character of this linen-and-cotton combination is based upon a hard-spun warp alongside a soft-spun, long-fibred weft, producing a cloth from which a nap can be raised by teazling the weft. Cloths of this character could be made equally well from a worsted warp and woollen weft, or a linen warp and woollen weft. After finishing by raising and shearing, fabrics of this category would have in common a soft, continuous surface nap of fibres, covering the weave structure beneath. Mazzaoui's study of medieval Italian 'fustians' found both plain and napped fabrics, and she notes that 'a corporation of nappers or finishers of cotton cloth received recognition in 1409' in Cremona. Kellenbenz mentions shearers amongst the workers of one of the Swabian fustian enterprises. ${ }^{16}$ Thus there is evidence that even the earliest European fustans included those with a raised finish. These would have employed longer-stapled grades of cotton, susceptible to forming a nap without unduly weakening the cloth. ${ }^{17}$

The unraised cotton mixture fabrics probably faced competition from home-produced fabrics, leaving the napped variety favoured in imports from Europe. And the English fustian production appears to have been limited mainly to those with a raised finish. Although there are exceptions, from 1600 onward, fustians in England can be characterised primarily by the raising of a nap or pile, sometimes sheared to develop their final appearance, and a mixture of yarn elements. ${ }^{18}$ The formation of the cloth from disparate elements, and its transformation from loom-state to a lofty surface, enables us to understand the figurative use of the word fustian that arose in the $1590 \mathrm{~s} .{ }^{19}$ Samuel Johnson gives this meaning as a "high swelling kind of writing made up of heterogenous parts'. ${ }^{20}$ Eventually, the linen-warp and cotton-weft variety gained the ascendant in England, followed later by all-cotton varieties. ${ }^{21}$ 
Some idea of the character of the napped fustian used in England is conveyed by a few authors. The yarn combinations would have produced a lighter fabric than the equivalent woollens, yet the raised surfacecould still keep out the wind. Copland writes in 1570 about outdoor clothing for spring: 'Shepardes keepe them selues metely well clothed, not ouer clothed, not ouercolde ne ouer hot, as with lynseywolsy, doublettes of fustian, and gownes of a meetely length' ${ }^{22}$ For providing a surface neither too smooth nor too rough, Smythe in 1594 recommends fustian or chamois skins for soldier's doublets as, 'a man may arme better vppon any of both those things, then vppon Canuas, or any thinge that is more smooth, and lesse woollie' ${ }^{23}$ Perhaps the most evocative description of the nap of fustian is provided by Charles Butler's recommendations for the beekeeperin 1634: 'Wool and Woollen doo not offend dem: and if beeing oderwise angered, dey strike deir Speeres in Woollen, dey can easily pul dem out again. But de nap of new Fustian displeaset dem, because it seemet hairy; and de stuf is so fast, dat it holdet de sting: werefore such apparrel is not fit among Bees' ${ }^{24}$ Thus the napped fustians, while not departing widely from the familiar appearance of English woollen cloths, were able to provide a lighter material of more moderate insulating quality, with a distinctive surface grain.

By the early-seventeenth century, English rate books allow us to roughly divide imported fustians into three categories by their relative value. ${ }^{25}$ The cheap varieties comprised jeane, Holmes, Bevernex, and Osbrow fustians which might have abrushed finish. Moderately-priced fustians such as barmillians, Millian, Dutch, Cullen, and Weazell fustians probably used a longer-fibred weft from which a considerable nap could be raised. The most expensive fustians were Naples fustians (alternatively fustianapes and variants) with a true cut pile. ${ }^{26}$ Fustian of Naples wasincluded in sumptuary legislation at the start of Edward IV's reign, and. Henry VIII's privy purse 
DRESS

expenses include a payment to 'the King's Coffer Maker for makyng a coffer covered with fustyan of Naples' around $1530 .{ }^{27}$ However, the middling grade of fustians held no such elite connotations; George Wiseheart's black 'Millian fustian' doublet was noted as an example of his modesty in dress in the $1540 \mathrm{~s} .^{28} \mathrm{Jean}$, at the bottom of the scale, seems already to have gained an association with working dress by the folbwing century. In 1638, the playwright Thomas Heywood (c1573-1641) gives an applicart for the post of schoolmaster the line, 'though I goe in genes Fustion, scalpellum et charta, I was not brought vp at Plowe $\&$ cart' ${ }^{29}$

By the end of the seventeenth century, fustian in men's wear is found as a protective overgarment, the frock, and in working clothing for craftsmen. The London Gazette advertised in 1675 for the missing son of a butcher stating he was dressed in 'asad coloured serge suit [with] a Fustian Frock over it ${ }^{30}$ In 1686, an Oxfordshire runaway aged eighteen is described, 'a gray cloth Suit on his back, underneath a Fustian Frock ${ }^{31}$ In a similar advertisement of 1687 , the dress of two runaway apprentices of a Tunbridge Wells carpenter is divided between best and working cldhes: 'The first is in a gray Suit for his best Cloaths, and Fustian for his Working. The other [...] his best Cloaths of light coloured Cloth, and his working of Fustian or Dimaty. ${ }^{, 32}$

John Houghton provides a brief description of the English fustian manufacture in 1701: 'With some cotton yarn, that we bring from abroad, and a great deal we spin at home, especially in Lancashire, and with some linen yarn we chiefly bring from Hamburg, we make dimities and fustians; the one being the warp, and the other the woof, which, when they are rowed, shear'd, press'd, and sometimes dyed, make a very considerable manufacture. ${ }^{33}$ Houghton understood the crucial role of the finishing procedures rowing, shearing and pressing - to developing the intended appearance of fustians 
which by the eighteenth century favoured the napped finishes. ${ }^{34}$ Rowing, derived from the word roughing, was a means of brushing to raise fibres from the loosely-spun cotton weft in order to form a nap. The rowing process is mentioned in a patent of 1671 by Edmond Blood whose newcloth made from silk waste was 'shagged by tezell or rowing cards, like as English bayes, rowed fustians, or dimatyes' ${ }^{35}$ Eric Kerridge cites inventories of fustian makers that list rowing frames amongst their equipment. ${ }^{36}$ And in 1706, the London Gazette advertised a runaway apprentice about seventeen years old, who had on a 'dark coloured Ro'd Fustian Frock lined with blue, with large Plate Buttons'. The Anders Berch Collection contains mid-eighteenth century examplesof such rowed or napped fustians that give an idea what English fustians looked like at this time. Berch formed his collection of manufacturing samples for the use of students of economics at the University of Uppsala in Sweden, and he obtained samples that demonstrate the stages of the finishing process proceeding from loom state to rowed, then pressed, and finished. ${ }^{37}$ While Berch's fustian is shagged, and intended to remain unsheared with a hairy appearance, sheared fustians would have presented a surface texture similar to milled wools $(1,1)$.

In commerce, wools were the main competitor of fustians. ${ }^{38}$ A pamphleteer of 1719 accusingly points to 'The Fustians now so generally worn by Men ofall Qualities, instead of Woollen cloth' ${ }^{39}$ Indeed, fustian was then associated with working dress amongst those of lower status, but equally encountered as underclothing, youth's clothing or sportswear amongst those of higher status. Differences of quality and finish would have further characterised fustians worn by those of high and low status. The mercer Joseph Symson wrote to John Lees in Manche\$er in 1718, 'I want about 15 yards of very fine white fustian, full as good or better than this pattern. I think you call them Dutch fustians [...] I desire you will put me a 15 yards piece of your finest and 
DRESS

thickest that's woolly and covers well. ${ }^{40}$ Lesser qualities would have been used for the frock used as riding wear by working men, and for servants' livery, the most frequently encountered uses offustian in the first half ofthe eighteenth century.

In the early eighteenth century, the frock could still be found as a protective overgarment, but also begins to be worn on its own. Joshua Allen wore 'a lightcoloured Fustian Frockover his Coat' when he went missing from his lodging in Chesterfield in $1714 .^{41}$ But Richard Bushell wore 'a Fustian Frock, Coat fashion' when he absconded with money from his master in Lincoln's Inn Fields in $1712 .{ }^{42}$ Livery fustians are usually distinguished by metal buttons. Thomas Tayler wore a 'Fustian Livery Frock with Brass Buttons' when making off with a sum of money in $1715 ;{ }^{43}$ and a negro boy called Robin workng in Bristol took with him 'a Suit of white Fustian with Metal Buttons' when he ran away in $1729 . .^{44}$

The 'white fustian frock' was often cited in descriptions of criminal suspects, such as John Winship of St Pancras, indicted for robbery in July 1721, who rode on a grey horse wearing a 'buttoned-up white Fustian Frock' ${ }^{45}$ So common was this article that a 1730 publication to assist magistrates provides a sample warrant for a suspect describing his dress as 'a dark brown Wig, and a white Fustian Frock fac'd with Black Cloth' ${ }^{46}$ White garments seem an odd choice for criminals, and one must assume that white fustian allowed them to blend in with the ordinary worker on horseback, rather than to stand out from the crowd. Such fustian frocks were equally the quarry and the dress of thieves; an account ofitems stolen in 1736 gives the valuation of a working man's stolen goods, with his fustian frock placed at 7 shillings, and his cloth coat at 10 shillings. ${ }^{47}$ The most famous of English highwayman, Dick Turpin, wore fustian to the grave. Executed at York for horse-stealing in April 1739, accounts of his end state that 
DRESS

'A few Days before his Execution, he bought himself a new Fustian Frock and a Pair of Pumps, in order to take his Leave of the World in as decent a Manner as he possibly could. ${ }^{48}$ It is tempting to think the material of Turpin's last coat may have been woven at York's new cotton manufactory, described by Daniel Defoe in his account of a tour in the North. Defoe observed a May Day parade in York in 1740 in which the 'Men, Women and Children employed in the Manufactory closed the Procession, all of them cloathed with Cottons, or striped and figured Fustians of their own making ${ }^{49}$ Although the colour of Turpin's frock is not recorded, he may have chosen fustian as a fabric available in white for its symbolic meaning, rather than from a preference for fustian among the criminal confraternity. ${ }^{50}$

Ribbed forms of fustian were introduced by the mid-1720s. An apprentice plumber from Oxfordshire wore 'a light-colour'd Thickset Fustian Frock, his Breeches the same' when he ran away in $1725 .{ }^{51}$ An apprentice apothecary wore 'a light ribb'd new Fustian Coat' when he left his master in Devon the same year. ${ }^{52}$

A 'working frock' is mentioned in an account of experiments with electricity from the Philosophical Transactions of the Royal Society in 1748. A man giving his epileptic son shock treatments relates that his son 'being [...] very high electrified, andhaving on a coarse Fustian working Frock [...] to my great Surprise, the furzy Flax of the Frock caught Fire with a great Blaze'. Possibly caring more for his science than his son's treatment, the man continues, 'At 9 the same Evening I made him put on the same Frock, and touch'd the left Arm where the Flax had not been burnt before, and it had the same Effect. ${ }^{53}$ This tendency of cotton garments to take fire must have been a real hazard for waiting men, but fustian garments for serving had a long pedigree, being mentioned by Shakespearein the 1590 s, an association probably derived from the 
correlation of white clothes and cleanliness. ${ }^{54}$ In a fictional account written around 1750 that centres on the concept ofgood blood and pedigree, an aristocrat is disguised in a waiter's suit, that is 'a white Fustian Frock, and white linen waistcoat [...] girt round [...] with the Waiter's Apron' ${ }^{55}$ A waiter in such dress can be seen in Hogarth's Captain George Graham in his cabin painted around 1745 (Fig. 2).

Amongst those of higher status, fustian figures amongst older menfor undress or undergarments. The author of an essay on ghosts, published in 1720, describes the spinit of a former country landowner 'dressed ashe was in life [...] it has Fustian Drawers on' ${ }^{56}$ The ageing Jonathan Swift wrote to a friend in September 1721 to ask 'if a messenger goes from hence, to give him my fustian waistcoat, because the mornings grow cold ${ }^{57}$ However, records show that younger men of higher status began to adopt fustian as an outer garment fabric by the 1710s, possibly apeing coachmen's dress which was perceivedas sporty. The Spectator remarks on 'a lively young Fellow in a Fustian Jacket [who] beckon'd a Coach, and told the Coachman he wanted to go as far as Chelsey: They agreed upon the Price, and this young Gentleman [then] mount[ed] the Coach-box. ${ }^{98}$ Likewise, in William Chaigneau's novel The History of Jack Conner, published in 1752, a young gentleman due to come into a Yorkshire estate of $£ 4000$ a year is sighted in the theatre wearing 'a white Fustian Frock and chequer'd Flannel Waistcoat, with the Hat of a Stage Coachman, ${ }^{59}$ Fustian is also connected with other forms of sporting dress. Bartholomew Greenwood, a gentleman of Camberwell who was indicted for assault in 1740 claimed to be elsewhere at the time. In his defence, he relates that his dinner companion on the evening in question saw him 'dressed in a white Fustian Frock, [...] Breeches of the same Stuff, a white Waistcoat, and, as he apprehended, I came from the Tennis-Court' ${ }^{60}$ A tennis costume of this nature can be 
DRESS

seen in a portrait painting of the first half of the eighteenth century recordedin the Witt Library, Courtauld Institute of Art, London. ${ }^{61}$

Some general trends in the wearing of fustian, especially among young men of the labouring class, can be charted in the proceedings of the Old Bailey which provides evidence for both urban and rural areas surrounding London. A tabular summary of occurrences of stolen fustian clothing shows that fustian frocks gained frequencyin wear during the 1710 s, peaked at mid-century, and then fell off sharply after 1770 . As the fustian frock waned, the fabric was increasingly taken up as a material for breeches (Table 1). Clothing worn by accused suspects has been left out of this tabulation. From the 1810 s onward, the suspect is more often wearing fustian than stealing it; and there is a sharp increase in the wearing of fustian jackets. Like their earlier counterparts, those with criminal intent probably wore fustian jackets to pass unnoticed among the mass of labouring men. ${ }^{62}$

Table 1. Stolen fustian clothing in the Old Bailey Proceedings Online ${ }^{63}$

\begin{tabular}{|c|c|c|c|c|c|c|}
\hline & Frock & $\begin{array}{c}\text { Breeches }+ \\
\text { Trousers }\end{array}$ & Waistcoat & Coat & $\begin{array}{l}\text { Length } \\
\text { s of } \\
\text { cloth }\end{array}$ & Miscellaneous \\
\hline $1680 \mathrm{~s}$ & 1 & 0 & 1 & 0 & 2 & 2 drawers \\
\hline $1690 \mathrm{~s}$ & 2 & 0 & 0 & 0 & 2 & 2 petticoats \\
\hline $1700 \mathrm{~s}$ & 1 & 0 & 1 & 0 & 0 & - \\
\hline $1710 \mathrm{~s}$ & 8 & 1 & 1 & 0 & 6 & - \\
\hline $1720 \mathrm{~s}$ & 14 & 0 & 2 & 2 & 2 & - \\
\hline $1730 \mathrm{~s}$ & 7 & 1 & 1 & 2 & 0 & 1 purse \\
\hline $1740 s$ & 12 & 2 & 1 & 0 & 5 & 1 gown \\
\hline $1750 \mathrm{~s}$ & 16 & 3 & 3 & 2 & 3 & 1 pr sleeves \\
\hline $1760 s$ & 13 & 1 & 5 & 2 & 2 & - \\
\hline $1770 \mathrm{~s}$ & 1 & 8 & 1 & 0 & 1 & 3 pockets \\
\hline $1780 \mathrm{~s}$ & 2 & 9 & 3 & 3 & 1 & $\begin{array}{l}1 \text { jacket } \\
1 \text { pocket }\end{array}$ \\
\hline $1790 \mathrm{~s}$ & 2 & $4+1$ & 0 & 0 & 4 & $\begin{array}{l}2 \text { jackets } \\
1 \text { pocket }\end{array}$ \\
\hline $1800 \mathrm{~s}$ & 0 & $1+0$ & 0 & 1 & 1 & 2 jackets \\
\hline $1810 \mathrm{~s}$ & 0 & 0 & 0 & 0 & 5 & - \\
\hline
\end{tabular}


DRESS

\begin{tabular}{|l|l|l|l|l|l|l|}
$1820 \mathrm{~s}$ & 4 & $1+5$ & 0 & 22 & 3 & 1 jacket \\
\hline
\end{tabular}

John Cleland's famous erotic novel, Memoirs of a Woman of Pleasure written in the 1730s, provides evidence that at that date fustian was not yet associated with country dress. ${ }^{64}$ A nineteen-year-old protagonist 'in a white fustian frock, with a green velvet cape, and a cut bob-wig' is accompanied by a younger man described as 'a country lad by his dress.' The latter wears 'a green plush frock, and breeches of the same, white waistcoat and stockings' with a jockey cap and natural long hair. ${ }^{65}$ Plush was not a fabric of the fustian group, but a true velvet with a cut pile of combed wool. ${ }^{66}$

Around mid-century, white fustian began to receive competition from other fabrics for working attire. New duties upon imported canvas drilling were suggested in 1766 because it was hurting the fustian manufacture of Lancashire. Drilling was described as 'a species of coarse linnen, worn for men's frocks, and brewer's and distiller's aprons ${ }^{97}$ By 1770 , the fustian frock appears to have been largely supplanted for fashionable wear by new materials, although it continued in use for men's breeches, and seems to have become associated with occupations involving ink, thus returning to a form of protective dress. The schoolmaster is characterised by his fustian breeches, ${ }^{68}$ the scrivener by his ink-splattered fustian breeches,${ }^{69}$ and the exciseman by his brown fustian suit with 'an ink-horn pendant from the buttonhole of the fourth. ${ }^{70}$

There is a suggestion that white fustian may have been adopted for ladies' dress in the 1770s. Around 1773, a Bath tailor and haberdasher advertised 'A Ladies White Jean Riding Dress [at] $£ 2$ 10s'. ${ }^{71}$ Later still, white fustian reappears as sailor’s dress. Dorothy Wordsworth describes an elderly saibr become beggar in 1801: 'His breeches were either of fustian, or grey cloth, with strings hanging down, whole and tight. ${ }^{72}$ One reason for adopting white or undyed fustian before the 1770s mayhave been the 
difficulty in obtaining fast dyes on cotton. Thomas Henry read a paper before the Manchester Literary and Philosophical Society in 1786 in which he stated, 'Till within these few years, the colours employed in the dy[e]ing of fustians and cotton velvets were few, and even at this day, many of them are fugitive. ${ }^{73}$ Most earlier eighteenthcentury references to dyed fustian are either to 'sad' colour, snuff colour, or brown. ${ }^{74}$

It was the pile weave fustians that were to expand greatly in use durng the last half of the eighteenth century. These were fabrics with a supplementary weft that was cut after weaving with a specially adapted knife in order to form a pile (Fig. 3).Weft floats for cutting could be distributed evenly to yield velveteens, or aligned in parallel furrows to form cords (Fig. 4). The introduction of pile-woven cottons to Lancashire is documented in the Manchester Weavers' Case concerning an annual tithe on looms which ran in the courts between 1749 and 1753. The testimony of dozens of weavers and finishers in the Manchester region was invoked. This extensive body of evidence was reviewed by Alfred P. Wadsworth in 1931, including a footnote touching on the introduction of cotton velvets to Lancashire. ${ }^{75}$ Returning to the original documents, it is found that John Barlow, calenderer from Manchester testified in 1745 that 'a Loom or Engine of a late Invention [was] set up in the Town of Manchester [...] for the making or weaving of flowered cottons commonly called Cotton Velvets'. He went on to say 'that it was first introduced to Bolton [...] about a year or two before [...] [and] a Weaver from Bolton was procured to set up that before mentioned in Manchester. ${ }^{76}$ This 1745 date tallies with the annotated samples provided by Jdhn Holker, an expatriate English calenderer, to the Académie Royale des Sciences in 1750. Holker claimed to have worn a cloth similar to his sample of flowered cotton velvet for three years, thus dating it no later than 1747; he went on to say that it had improved in 
DRESS

appearance with use. ${ }^{77}$ Anders Berch also obtained samples of Manchester velvets in the late 1740 s that are now held in the Nordiska Museet. ${ }^{78}$

After the mid-century homemanufacture of pile weave cottons, the term fustian can no longer be assumed to refer to napped flat-woven clah, but judgements must be made based on context or cost. Barbara Johnson opts for a simpler brushed jean-type fabric for her fustian riding habit of 1757. But during the second half of the eighteenth century, fustian is increasingly applied to velveteens, velverets, and the corded pile weaves we now call corduroys. It may well be such pile fabric that is referred to in Tobias Smollett's novel of 1753, Ferdinand Count Fathom. Count Fathom astonishes Paris, 'habited in the exact uniform of an English jockey [...] leathern cap, cut bob [wig], fustian frock, flannel waistcoat, buff breeches, hunting boots and whip'. The frock is later said to have cost 'but forty shillings'. A servant's 'Fustian Frock lined throughout' cost one guinea around 1769 , only half the price. ${ }^{79}$ Comparable to Count Fathom's frock is the 'Thickset Frock and Waistcoat' for two guineas, advertised by the tailor John Manningford of Bath in $1773{ }^{80}$ Thickset is one of the pile weave fustians, which we would now call narrow-walecorduroy, a step below velveret and velveteen.

It was to be this 'jockey's uniform' that both young townsmen and countrymen adopted for riding and informal wear from the mid-century. Adam Fitz-Adam, describing the races at Newmarket in 1753, wrote: 'Everybody is dressed so perfectly alike that it is extremely difficult to distinguish between his Grace and his Groom. [...] Those who have been at this place will not be surprised at these mistakes, for a pair of boots, and buckskin breeches, a fustian frock with a leather belt about it, and ablack velvet cap is the common covering of the whole town. ${ }^{91}$ The Connoisseur of 1756 reports, 'the gentlemen $[\ldots]$ have taken pains to convert themselves inb coachmen, grooms and 
DRESS

jockies [evidenced by] the flapped hat, the jemmy frock with plate buttons and a leathern belt, and the pride which some young gentlemen of quality take in driving, ${ }^{82}$ Two decades later, a comic romance of 1773 still speaks of 'a well booted Grecian, in a fustian frock and jockey cap ${ }^{83}$ However, by the $1780 \mathrm{~s}$, the townsman seems to tire of jockey clothes, although they are retained by his country cousin. Thomas Rowlandson's Four o'clock in the town shows a dissipated young buck returning home in cocked hat and pumps, whereas Four o'clock in the country depicts a bleary-eyed young hunter still donning jockey boots and cap (Fig. 5). This pair of watercolours was painted in 1788 , and etched for publication in 1790 . It is probably not going too far to suggest that Rowlandson was picking up on a recent phenomenon - an increasing distinction between town and country dress.Rowlandson had produced anearlier pair of town and country prints, his 1785 Nap in Town and Nap in Country, possibly first marking the growing social separation.

Certainly by the 1790 s, fustian had become linked to country wear, and could be worn by the country gentleman as well as the farmer. In a novel of 1791, a gentleman of small estate living 'the pastoral life in all it primitive simplicity [...] was so absorbed in his attention to his fields, his cows, his poultry, and his pigeons, that he had not for some time, except on a Sunday, been observed to lay aside his fustian frock and put on a dressed coat' ${ }^{84}$ A traveller of 1795 notes on the opposite side of the carriage 'a dozing farmer, in his best fustian suit' ${ }^{85}$ Between 1770 and 1785, all-cotton pile weave fustians and their finishing was brought to greater perfection. John Aikin credits John Wilson of Ainsworth with the development of "various means of rubbing and brushing the piles, clearing off the loose hairs with razors,' later dressing the cloth over irons heated by stoves to singe off any uneven fibres, followed by bleaching before dyeing. ${ }^{86}$ The finer 
finish and better penetration of dyestuff served to make such fustians acceptable to elite wearers for country pursuits (Fig. 6).

An equally notable conquest of fustian was that of substituting for leather or doeskin breeches. An army doctor advises, 'The custom so prevalent in the amy of men wearing leather breeches is by no means a good one [...] during wet weather they are perfectly intolerable $[\ldots]$ We are quite certain that if a buff-coloured cotton velvet, which may be had for three shillings per yard, were substituted for leather, it would be found both a durable and a much more comfortable wear. ${ }^{87}$ It was the pile-woven cotton fabric's ability to shed light rain, or to dry quickly when soaked, that probably endeared it to the countryman, necessarily more exposed to the vagaries ofBritish weather. It seems a considerable irony that the country landowner adopted this factoryspun, mill-woven, importedfibre, while the town gentleman was to become characterised by tailoring of the finest broadcloth from wool raised in the British countryside.

New uncut types of fustian were next to evolve, most notably moleskin. It is difficult to place the date of this development as the term moleskin was also adopted for wool coatings. ${ }^{88}$ However, there are some indications that this took place in the $1790 \mathrm{~s}$. A Lincolnshire baker who went missing in 1795 is described wearing 'a Fustian Jacket, a Pair of Corduroy Breeches' and took with him 'a darkish Velveret Waistcoat' ${ }^{99}$ It can be presumed in this case that the material of the jacket, identified only as fustian, was not a pile weave type but a napped variety. J. Herbert Cooke claimed that, if suitably finished, moleskins 'would stand even the rough wearof the blacksmith and the riveter, even turning sparks aside without suffering injury ${ }^{90}$ It is probably these types that began to be adopted by those town workers who could aford the better qualities for 
making the increasingly popular fustian jackets. The downy nap ofmoleskin was not only more fire-resistant, but would not catch the dust of mills and factories.Country workers, on the other hand, leaned toward the pile textures, and eventually returned to wool mixtures. A Select Committee on the State of the British Wool Trade in 1828 asked a London wool dealer:

Is there not at the present Time a considerable Use of Cotton Goods, in the Shape of Fustians and Velveteens, that are substitutes for Woollen Goods?', who replied - There are a certain Description of Goods manufactured of Cotton and Wool together, called Woollen Cords... which the Famers use for Breeches, of which Cotton is One Third Part, they will wear for a long while and look well; and Farmers Men have a great Liking, in consequence of the Length of Wear, to have those Patent Cords, which are made partly of Cotton and partly of Wool; and therefore that Article is very much consumed by Farmers Men, Waggoners and Agriculturalists, as well as by the manufacturing poorer Classof the Community. ${ }^{91}$

Fustian had becomea favourite with labouring men for all its hard-wearing and protective qualities, but it lacked the superb malleability and drape of woollen broadcloth that enabled the transformation of British tailoring in the early nineteenth century. This resistance to shaping inevitably relegated fustian -apart from the best velveteens and thicksets used by the sporing gentleman - to the working mans' wardrobe, and enabled it to develop into a symbol of the labouring man in the nineteenth century. By early Victorian times, the differences between working-class and middle-class men were able to be pithily summarised as confrontations between 'fustian and broadcloth. ${ }^{92}$ 


\section{${ }^{1}$ ACKNOWLEDGEMENTS}

I would like to thank Christine Stevens for helping with the initial idea for this paper, and Dr Miles Lambert for his assistance in the study of men's fustians at the Gallery of Costume, Platt Hall. Mary Harrison of Manchester Metropolitan University Library has provided invaluable help in using electronic resources through her weekly bulletins for researchers.

\section{REFERENCES}

Thomas Hughes, Tom Brown's Schooldays by an Old Boy (London: Macmillan and Co., 1897), p. 27. (first published in 1857). The description continues: 'with rough plush waistcoats of many colours [...]'

${ }^{2}$ P. A. Pickering, 'Class Without Words: Symbolic Communication in the Chartist Movement', Past and Present, no. 112 (1986), p. 161, note 73. I am grateful to the editors of Costume for bringing this article to my attention.

${ }^{3}$ M. F. Mazzaoui, The Italian Cotton Industry in the Later Middle Ages 1100-1600 (Cambridge: Cambridge University Press, 1981), pp. 29-32, 90-92, and 166-167.

${ }^{4}$ Ibid., p. 64 and note 19, p. 189. It is not stated by Mazzaoui under what name these fabrics were purchased.

${ }^{5}$ H. Kellenbenz, 'The Fustian Industry of the Ulm Region in the Fifteenth and Early Sixteenth Centuries', in: N. B. Harte \& K. G. Ponting (eds), Cloth and Clothing in Medieval Europe (London: Heinemann Educational Books for The Pasold Research Fund, 1983), pp. 259-276.

${ }^{6}$ Ibid., p. 270.

${ }^{7}$ The National Archives (PRO). SP $1 / 214$, f. 24 . The word begins fust, but appears to contain a contraction before ending $n s$

${ }^{8}$ Anno xi henrici vij Statuta bonu[m] publicum concerne [n]tia edita in parliamento tento apud westmonesterium xiiij die Octobris ano regni illustrissimi Domini nostri regis Henrici septimi (Westminster: Wynkyn de Worde, 1500?), sourced from EEBO images 25-26.

${ }^{9}$ Pascale Gorguet Ballesteros cites the excavations of 1985-1987 in the rue de Lutèce in Paris that brought to light thirteenth to fifteenth-century fustians of wool and cotton, as well as linen and cotton, in a context of non-elite consumption. See Ballesteros, 'Le Coton au Moyen Age: Rembourrage et Futaines' in Musée Galliera, Le Coton et la Mode: 1000 Ans d'Aventures (Paris: Somogy for Paris Musées, 2000), p. 34.

${ }^{10}$ F. Blomefield, An Essay Towards a Topographical History of the County of Norfolk... (Lynn: Fersfield, 1739), p. 192; J.Arnold, Queen Elizabeth's Wardrobe Unlock'd (Leeds: Maney, 1988), p. 143.

${ }^{11}$ Wool fustians may have had characteristics resembling their later linen-cotton counterparts in requiring raising and shearing., see J. Washington (ed.), An Exact Abridgment of All the Statutes in Force and Use from the Beginning of Magna Carta (London: Her Majesties Printers, 1708), p. 286.

${ }^{12} \mathrm{O}$. Sansom, An Account of Many Remarkable Passages of the Life of Oliver Sansom ... (London: J. Sowle, 1710), p. 418.

${ }^{13}$ To the honourable knights, citizens, and burgesses, of the Commons House of Parliament the humble petition as well, of divers merchants and citizens of London that vse buying and selling of fustians made in England, as of the makers of the same fustians (London, 1621), broadsheet. This reference was first highlighted by W. H. Price, 'On the beginning of the cotton industry in England', Quarterly Journal of Economics, vol. 20 (1906), p. 610.

${ }^{14}$ See, for example, T. Sprat, Bishop of Rochester, The History of the Royal-Society of London, for the Improving of Natural Knowledge (London: Scot, Chiswell, Chapman and Sawbridge, 1702), p. 293: In the early eighteenth century, fustians became divorced from wool and linen fabrics in trade statistics. See, for example, Anon., A List of the Names of All the Commodities of English Product and Manufacture that was Exported to France from England During What may be Call'd the Interval of Peace from Christmas 1698 to Christmas 1702 (London: B. Tooke, 1713), pp. 2-4.

${ }^{15} \mathrm{E}$. Ward, The modern world disrob'd: or, both sexes stript of their pretended vertue (London: G. S., 1708), p. 150.

${ }^{16}$ M.F. Mazzaoui, The Italian Cotton Industry in the Later Middle Ages 1100-1600 (Cambridge: Cambridge University Press, 1981), p. 110. H. Kellenbenz, 'The Fustian Industry of the Ulm Region in the Fifteenth and Early Sixteenth Centuries', in: N. B. Harte \& K. G. Ponting (eds.), Cloth and Clothing in Medieval Europe (London: Heinemann Educational Books for The Pasold Research Fund, 1983), p. 267.

${ }^{17}$ As unfinished cloth would have been less bulky and easier to transport, it was likely to have been imported to England in the unfinished state, once sufficient craftsmen were available to carry out the finishing process at home.

${ }^{18}$ As with any textile designed for a particular finish, it can be sold in the unfinished state. This can give rise to other uses and developments. For example, the weave types that we now know as Bedford cords appear to have developed from the unfinished state of types originally intended to be cut as corduroy.

${ }^{19}$ The Oxford English Dictionary cites Marlowe's Faustus, written in the 1590s, as an early occurrence of the figurative meaning of fustian. Clown, commenting on Wagner's mixture of Latin and English, responds 'God forgive me, he speaks Dutch fustian.' Christopher Marlowe, The tragicall history of D. Faustus (London: S. Simmes for Thomas Bushell, 1604, sourced from EEBO image 8.

${ }^{20}$ Samuel Johnson. A Dictionary of the English Language (London: J. Knapton et al., 1756), vol. 1, q.v. Fustian.

${ }^{21}$ It has been seen that fustian is not necessarily a linen-and-cotton mixture fabric. Neither are all linen-and-cotton mixtures fustians. Calico printers successfully avoided the ban on printing cotton calicoes, by using un-raised fustian, or cloth woven to appear as such. A petition of London weavers to the House of Commons in 1735 claimed that a linenand-cotton mixture cloth 'improperly called by the Name of Fustian, hath been invented in this Kingdom, and great 
Quantities are now made thereof which, when printed, cannot, without the greatest Difficulty, be distinguished from an Indian Callicoe.' Journal of the House of Commons, vol. 22, 25 Feb 1735, p. 589.

${ }^{22}$ R. Copland. The Shepardes Kalender (London: Thomas Este for John Wally, 1570), sourced from EEBO image 66.

${ }^{23}$ J. Smythe, Sir [Certen] Instruct[ions, Observati]ons and Orders Militarie Requisit for all Chieftaines... (London:

Richard Johnes, 1594), p.184. Sourced from EEBO, the title page for the copy used for Early English Books Online is imperfect, and the complete title was conjectured from the Short Title Catalogue.

${ }^{24}$ C. Butler, The Feminine Monarchie, or, the Histori of Bees (Oxford: William Turner, [1634]), p. 10.

${ }^{25}$ See, for example, The Rates of Marchandizes, as They are Set Downe in the Booke of Rates...(London: F. Kingston, 1608), sourced from EEBO image 30; The Rates of Marchandizes, as They are Set Downe in the Booke of Rates...

(London, F. Kingston, [1623(?)], sourced from EEBO images 31-32; The Rates of Marchandizes, as They are Set Downe in the Booke of Rates...(London: Robert Barker, 1635), sourced from EEBO image 26.

${ }^{26}$ While most of these fustians were named after their place of origin, fustian of Naples is not thought to originate from that city. For example, Blundeville gives Belgium as a source for 'Fustianapes of Vellures.' See: T. Blundeville, $M$. Blundevile his exercises containing sixe treatises... (London, John Windet, 1594), p. 251.

${ }^{27}$ N. H. Nicolas, Sir, The Privy Purse Expences of King Henry the Eighth, from November MDXXIX to December MDXXXII (London: William Pickering, 1827), p. 184.

${ }^{28}$ J. Foxe, Actes and Monuments of Matters Most Speciall and Memorable, Happening in the Church with an Vniuersall History of the Same... (London: John Daye, 1583), vol. 2, p. 1268.

${ }^{29}$ Thomas Heywood, The Wise-woman of Hogsdon: a Comedie. (London: M. P[arsons] for Henry Shephard, 1638), sourced from EEBO image 22. Probably not too much should be made of the agricultural reference as Heywood was aiming at comic effect in transliterating Latin to English.

${ }^{30}$ London Gazette, Issue 1065, 31 Jan 1675. Amos Garrett, the son of Seth Garrett, butcher, over against St. Olave's Church in Southwark.

${ }^{31}$ London Gazette, Issue 2226, 17 Mar 1686. Run away from his Master John Burt at Great Hazely in Oxfordshire.

${ }^{32}$ London Gazette, Issue 2240, 5 May 1687. Amiel Philips and Richard Clarke, run away from their Master, Thomas Bigg, a carpenter from Tunbridge Wells.

${ }^{33}$ J. Houghton, A Collection for the Improvement of Husbandry and Trade...Revised by Richard Bradley (London: printed for Woodman and Lyon, 1727-28), vol. 3, no. 465, 20 Jun 1701. While it is often assumed that the weft of mixture fabric fustians was the main end use of cotton fibre by the start of the eighteenth century, John Houghton claimed that the principal use of cotton was to imbibe the ink in ink-horns to prevent spilling. He notes that although the writing needs of any one household were small, the universality this use of cotton made the total consumption large. ${ }^{34}$ Phillips defines the sheerman's craft as 'an Art us'd at Norwich, where Worsteds, Stamins, and Fustians are Sheer'd, as well as all other Woollen Cloth.' See E. Phillips, The New World of Words; or, Universal English Dictionary...Revised by J. K. (London: J. Phillips, 1706), q.v. Sherman's-Craft or Sheerman's Craft.

${ }^{35}$ British Patent no. 165, 7 Nov 1671.

${ }^{36}$ E. Kerridge, Textile Manufactures in Early Modern England(Manchester: Manchester University Press, 1985), p. 303, note 33 .

${ }^{37}$ E. Stavenow-Hidemark, $18^{\text {th }}$ Century Textiles: the Anders Berch Collection at the Nordiska Museet (Stockholm: Nordiska Museets Förlag, 1990), p. 192.

${ }^{38}$ There is some evidence that fustians were also used a substitute for leather. Smythe (1594) equates fustian with chamois skins in its suitability for military use (see note 19).

${ }^{39}$ J. Asgill, A Brief Answer to a Brief State of the Question, Between the Printed and Painted Callicoes, and the Woollen and Silk Manufactures... (London: J. Roberts, 1719), pp. 14-15.

${ }^{40}$ S. D. Smith (ed.), 'An Exact and Industrious Tradesman': the Letter Book of Joseph Symson of Kendall 1711-1720 (Oxford: Oxford University Press for The British Academy, 2002), p. 614.

${ }^{41}$ London Gazette, Issue 5259, 11 Sep 1714, p.2. Joshua Allen, aged about 31, supposed to be troubled in mind.

${ }^{42}$ London Gazette, Issue 5042, 12 Aug 1712, p.2. Went away from Francis Annesley, Esq; in Lincoln's Inn Fields.

${ }^{43}$ London Gazette, Issue 5352, 2 Aug 1715, p.2. Thomas Tayler, aged about 26 years, went from his Master.

${ }^{44}$ London Gazette, Issue 6813, 13 Sep 1729, p.2. Run away from Nathaniel Day, Esq; of Bristol, a Negro Boy called Robin, aged 18.

${ }^{45}$ Select Trials at the Sessions-House in the Old-Bailey, for Murder, Robberies, Rapes, Sodomy, Coining, Frauds and other Offences (London: Old Bailey, 1742), vol. 1, pp. 48-51. Found guilty, Winship was executed at Tyburn, 21 July 1721 , aged 22.

${ }^{46}$ J. Harvey, J. P., A Collection of English Precedents, Relating to the Office of a Justice of Peace (London: E. \& R. Nutt and R. Gosling, 1734), p. 154.

${ }^{47}$ Court of Sessions, City of London and County of Middlesex, The Proceedings at the Sessions of the Peace, and Oyer and Terminer, for the City of London, and County of Middlesex (London: J. Roberts, 1737), session of 11 Jan 1736.

${ }^{48}$ The Genuine History of the Life of Richard Turpin, the Noted Highwayman ... the Whole Collected from Well Attested Facts, and Communicated by Mr Richard Bayes... (London: J. Standen, 1739), p. 32. The various published accounts of Turpin's life seem to derive from an original account published in the York Courant. 
${ }^{49}$ D. Defoe, $A$ Tour Thro' the Whole Island of Great Britain ... $4^{\text {th }} \mathrm{ed}$. with very great additions... which bring it down to the year 1748, vol. 3 (London: S. Birt, T. Osborne, D. Browne, J. Hodges, J. Osborn, A. Millar and J. Robinson, 1748) pp. $180-81$.

${ }^{50}$ There were historic precedents for this, such as the Duke of Norfolk's execution in 1572 . The moments before his execution are recorded: 'He rose up and pulled of his Velvet Gown, his Black Sattin Doublet, and his Velvet Night-cap, and gave them to the Executioner, and being in a White Fustian Wastcoat, he said to Mr. Dean of Pauls, this is the White Sattin Doublet I made to die in, which the Preacher did speak of, and so kneeling down at the Block...' See M.D., $A$ Brief History of the Life of Mary, Queen of Scots, and the Occasions that Brought her and Thomas, Duke of Norfolk, to Their Tragical Ends (1681).

${ }^{51}$ London Gazette, Issue 6416, 12 Oct 1725, p. 2. William Crouch, Son of John Crouch, of Great Tew, about 18 Years old, apprentice to William Scriven, Plumber and Glazier in Woodstock, Oxfordshire.

${ }^{52}$ London Gazette, Issue 6432, 7 Dec 1725, p. 2. John Tomkins, 22 years old, son of Mr. Thomas Tomkins, at Sisterwood, run away from his master Mr Thomas French, apothecary, in Axminster, Devon.

${ }^{53}$ Royal Society (Great Britain), 'A Letter from Mr Robert Roche to the President, of a Fustian Frock being set on Fire by Electricity’, Philosophical Transactions, vol. 45 (1748), pp. 323-24.

${ }^{54}$ W. Shakespeare, Mr. William Shakespeares Comedies, Histories, \& Tragedies Published According to the True Originall Copies (London: Isaac Iaggard and Ed. Blount, 1623), p. 221. From Taming of the Shrew, Act IV, Scene 1. Grumio [servant to Petruchio]: 'Where's the Cooke, is supper ready, the house trim'd, rushes strew'd, cobwebs swept, the seruingmen in their new fustian, the white stockings, and euery officer his wedding garment on?'

${ }^{55}$ The Mock Monarchs, or the Benefits of High Blood (London: Stanley Crowder and Henry Woodgate, 1754?), vol. 1, pp. 94-95.

${ }^{56}$ T. Gordon, The Humourist: Being Essays Upon Several Subjects (London: W. Boreham, 1720), p. 84.

${ }^{57}$ J. Swift, Letters, Written by Jonathan Swift, D.D., Dean of St Patrick's, Dublin, and Several of his Friends. From the year 1703 to 1740 (London: T. Davies, R. Davis, L. Davis and C. Reymers, 1767), vol. 2, p. 214, Letter CCXVI, 14 Sep 1721, Dr Swift to Mr Worrall. Swift was then aged 53.

${ }^{58}$ The Spectator, vol. VII, no. 498 (1713), p. 132.

${ }^{59}$ W. Chaigneau, The History of Jack Connor (London: W. Johnston, 1752), vol. 1, p. 230.

${ }^{60}$ B. Greenwood, The Case of Bartholomew Greenwood Submitted to the Publick by Himself(London: T. Cooper, 1740), p. 12.

${ }^{61}$ See Alan Mansfield and Phillis Cunnington, English Costume for Sports and Outdoor Recreation (London: Black, 1969), pl. 16; M. Wingfield, Sport and the Artist, vol. 1, Ball Games (Woodbridge: Antique Collectors Club, 1988), p. 307.

${ }^{62}$ I searched under the terms fustian, thickset, velveret, velveteen, and corduroy/corderoy. It was necessary to read sufficient of each record to ascertain the context and to eliminate figurative uses of the word fustian. Accounts with insufficient clarity were eliminated. Only stolen goods were tabulated, as it was felt that including the clothing worn by suspects prejudiced the figures toward the lower end of the social scale.

${ }^{63}$ Old Bailey Proceedings Online ( $<$ www.oldbaileyonline.org $>$ ) compiled over a period of several weeks in August 2007. The Old Bailey Proceedings Online has added new material since this research was done, and the searching mechanism has been improved.

${ }^{64}$ The book was published in 1749 , but Cleland later claimed to have written the novel as a young man in the $1730 \mathrm{~s}$, with the purpose of showing his East India Company colleagues that it was possible to write about a prostitute without using vulgar language.

${ }^{65}$ Neither of these two lads remains dressed for long, giving Cleland ample opportunity to demonstrate 'a dazzling variety of metaphors for parts of the body and sexual acts.' See P. Sabor, 'John Cleland (1710-1789)' in: Oxford Dictionary of National Biography (Oxford: Oxford University Press, 2004-7) <www.oxforddnb.com>

${ }^{66}$ Plush weaving had centres separate from fustian weaving, for example Banbury, where it flourished from the mideighteenth century, continuing until the early years of the twentieth century.

${ }^{67} \mathrm{C}$. Townshend, 'State of the nation in the years 1766 and 1767', A Collection of Scarce and Interesting Tracts (London: J. Debrett, 1787-88), vol. 2, p. 221.

${ }^{68}$ J. Hawthorn, Poems by John Hawthorn, Light Dragoon in the Inniskilling Regiment (Salisbury: for the author, 1779), p.10. 'His shoes were black, as black as ball could make 'em,/ His buckles wash'd, I did for plate mistake 'em;/ His stockings clouded, and his breeches fustian;/ Knee buckles bright, and not a bit of rust on...'

${ }^{69}$ The progress of love, or the history of Stephen Elliot (London: L. Wayland for T. Vernor, 1789), vol. 3, p. 7. '....as Elliot was walking down Fleet-street, he perceived his friend Filmer just coming out of the entrance of the Temple. He appeared to have undergone a new metamorphosis; for he was now clad in an old black coat and waistcoat, worsted stockings, and fustian breeches, all bespattered with ink. He was amazed at seeing his old friend, whom he did not imagine to be in town, as he had not called on him; and poor Filmer was ashamed to be seen by him in his present dress...'

${ }^{70}$ T. Cogan, John Buncle, Junior, Gentleman (London: J. Johnson, 1776-78), p. 159. 'A brown fustian suit of clothes, a dusky wig well oil'd, but clear of powder, a neat pair of ribbed worsted stockings, an old hat cock'd to the best advantage, a graduated walking stick, and an ink-horn pendant from the button hole of the fourth, told all the world, this is the Exciseman.' 
${ }^{71}$ John Maningford, Taylor, Hosier and Haberdasher (Bath: S. Hazard, [1773(?)], broadsheet sourced from ECCO.

${ }^{72}$ W. Knight (ed.), The Journals of Dorothy Wordsworth (London: Macmillan \& Co, 1897), vol. 1, p. 73. Letter from Dorothy Wordsworth, 3 Dec 1801.

${ }^{73}$ T. Henry, 'Considerations Relative to the Nature of Wool, Silk, and Cotton as Objects of the Art of Dying, \&c.', Memoirs of the Literary and Philosophical Society of Manchester, vol. 3 (1790), p. 348. Paper first read 20 Dec 1786.

${ }^{74}$ Snuff coloured: London Gazette, Issue 5622, 4 Mar 1718, p. 2; dark brown: London Gazette, Issue 6222, 3 Dec 1723, p. 3; brown: London Gazette, Issue 6402, 24 Aug 1725, p. 1; sad-coloured: London Gazette, Issue 7010, 3 Aug 1731, p. 1; brown: London Gazette, Issue 9555, 14 Feb 1756, p. 2; brown: London Gazette, Issue 9900, 29 May 1759, p. 4.

${ }^{75}$ A. P. Wadsworth \& J. de Lacy Mann, The Cotton Trade and Industrial Lancashire 1600-1780 (Manchester: Manchester University Press, 1965), p. 174. First published 1931

${ }^{76}$ National Archives, PRO. E145/25Geo2/Hil2. Exchequer: Commissions.

${ }^{77}$ F. M. Montgomery, 'John Holker's Mid-Eighteenth-Century Livre d'Echantillons' in: V. Gervers (ed.), Studies in Textile History (Toronto: Royal Ontario Museum, 1977), p. 219.

${ }^{78}$ E. Stavenow-Hidemark, $18^{\text {th }}$ Century Textiles: the Anders Berch Collection at the Nordiska Museet. (Stockholm: Nordiska Museets Förlag, 1990), p. 191.

${ }^{79}$ Margaret Moffat, at the Golden Key and Star, in Lancaster-Court in the Strand, near St. Martin's Church...(London, 1769?), broadsheet.

${ }^{80}$ John Maningford, Taylor, Hosier and Haberdasher (Bath: S. Hazard, [1773(?)], broadsheet. Anne Buck notes 'a fustian coat and waistcoat costing £3.16s' bought in 1758 by John Salusbury, a small landowner of Leighton Buzzard. Estimating the waistcoat at half the cost of the coat, he would have paid around fifty shillings for his fustian coat, which might have been a velveret or one of the better quality cotton pile fabrics. See A. Buck, Dress in Eighteenth-Century England (London: B.T. Batsford, 1979), p. 76.

${ }^{81}$ A. Fitz-Adam. The World, vol. 1, no. 17 (1753), pp. 98-99.

${ }^{82}$ Jemmy is defined by the Oxford English Dictionary as an obsolete dialectal term for spruce, neat or smart. $<$ http://dictionary.oed.com $>$

${ }^{83}$ R. Graves, The Spiritual Quixote: or, the Summer's Ramble of Mr Geoffry Wildgoose. A Comic Romance (London: J. Dodsley, 1773), vol. 3, p. 230.

${ }^{84}$ Flights of Inflatus (London: C. Stalker, 1791), vol. 1, p. 17. Sometimes attributed to Henry Man.

${ }^{85}$ The Observant Pedestrian; or Traits of the Heart in a Solitary Tour from Caernarvon to London (London: William Lane, 1795), vol. 1, p. 127. It is noteworthy that the farmer sits beside 'a stiff-starched antiquated virgin, who folded up the corners of her apron and fastened them with a pin, lest the dust of my shoes should soil it.' It is this care that the countryman took for clothing that was to become a characteristic trait, and the subject of satire. The pose of the town dweller, by contrast, was one of insouciance. When the countryman is depicted in out-of-date attire, it may not be so much to label him as unfashionable, as to express astonishment that he has preserved his old clothing in presentable form.

${ }^{86}$ J. Aikin, A Description of the Country from Thirty to Forty Miles Round Manchester (London: John Stockdale, 1795), pp. 163-165. The new method of dressing with red-hot irons was common enough by 1785 to warrant a petition by the fustian dyers. They found it impossible to preserve the frame mark on the cloth for goods requiring singing with the 'red-hot Dressing-Iron', and thus the property was at constant risk of seizure. See Journals of the House of Commons, vol. 40, 1784-85, p. 768.

${ }^{87}$ R. Somerville, Memoir on the Medical Arrangements Necessary to be Observed in Camps (London: T. Egerton, 1796), p. 44.

${ }^{88}$ Beaverteen was a fustian related to moleskin but somewhat less costly; it appears in advertisements of the 1820 s, and may have been developed to meet the increasing demand for fabrics of this type.

${ }^{89}$ London Gazette, Issue 13981, 18 Feb 1797, p.7. John Coulson, of Spalding, in the County of Lincoln, Baker, absented himself from his friends on 26 December, 1795.

${ }^{90}$ J. H. Cooke, The Velvet and Corduroy Industry (London: Sir Isaac Pitman \& Sons, 1922), p. 87.

${ }^{91}$ Journals of the House of Lords, vol. 60 (1828), Appendix no.3

${ }^{92}$ P. A. Pickering, 'Class Without Words: Symbolic Communication in the Chartist Movement', Past and Present, no.112 (1986) p. 161. An editorial of 1842 declaims, 'In one word, broadcloth clothed middle class will have the working class clad in fustian, because when itself shrinks beneath the haughty glance of coroneted aristocracy, it can relive itself by turning round and spitting on the fustian.' See 'Will the Middling Class Aid the Working Class to Obtain Universal Suffrage?', The Odd Fellow, 25 Jun 1842, p.2.

PHILIPA. SYKAS received his PhD from Manchester Metropolitan University where he is currently a Research Associate. He is working on the history of English printed textiles, their technology and culture, incorporating the evidence of pattern books and business archives. He recently published The 
Secret Life of Textiles (Bolton Museums, 2005) detailing textile archives in North West England. 